\title{
Races, disease symptoms and genetic variability in Pyrenophora tritici-repentis isolates from Oklahoma that cause tan spot of winter wheat
}

\author{
Kazi A. Kader ${ }^{1} \cdot$ Robert M. Hunger $^{1} \cdot$ Aswathy Sreedharan $^{1} \cdot$ Stephen M. Marek ${ }^{1}$
}

Received: 1 February 2021 / Accepted: 30 April 2021 / Published online: 21 May 2021

(C) The Author(s) 2021

\begin{abstract}
In recent years, tan spot of wheat caused by the fungus Pyrenophora tritici-repentis has become more prevalent in Oklahoma. Experiments were conducted to investigate the race structure, disease symptoms and genetic variability in $P$. tritici-repentis isolates collected from winter wheat over three decades. Race determination was conducted for 16 isolates based on expression of necrosis and/or chlorosis produced on wheat differentials. Variability in disease symptoms expressed by 12 isolates was determined on 13 hard red winter wheat cultivars grown in Oklahoma. In addition, genetic variability among 17 isolates was determined using amplified fragment length polymorphism-polymerase chain reaction (AFLP-PCR). All isolates except one (El Reno) were classified as race 1. Isolates varied widely in producing necrosis and/or chlorosis symptoms on wheat cultivars, but necrosis with a chlorotic halo was predominant (56.4\%). AFLP-PCR analysis using 13 primer pairs produced a total of 494 alleles of which 285 were polymorphic. The overall genetic diversity among the isolates was $25.2 \%$. Genetic relationships based on cluster analysis and principal component analysis showed only minor differences between isolates, and isolates did not form tight clusters or groups. The isolates of $P$. tritici-repentis were predominantly race 1 ; however, they produced a range of tan spot symptoms on wheat cultivars. The lack of distinct genetic grouping by the AFLP marker study indicates that the isolates used in this study likely originated from a single lineage.
\end{abstract}

Keywords Pyrenophora tritici-repentis · Genetic variability · Tan spot · Wheat

\section{Introduction}

Tan spot of wheat (Triticum aestivum L.) caused by the necrotrophic ascomycetes fungus Pyrenophora triticirepentis (anamorph: Dreschlera tritici-repentis (Died.) Shoemaker) is a major disease in many wheat-growing areas in the world (Francl et al. 1992; Bockus et al. 2010). In the Great Plains of the USA, tan spot causes considerable damage in wheat (Wegulo et al. 2012; Friskop and Liu 2016). A range of 3-50\% yield loss in wheat has been observed for tan spot depending on the isolate virulence, cultivar susceptibility and the environmental conditions (Shabeer and Bockus 1988). In Oklahoma in the southern Great Plains of the USA where wheat is grown annually on nearly 3-4 million acres

Robert M. Hunger

bob.hunger@okstate.edu

1 Department of Entomology and Plant Pathology, Oklahoma State University, Stillwater, OK 74078, USA
(NAAS 2019), tan spot disease has been reported since the 1970s (Hunger and Brown 1987). Currently, the presence of tan spot in Oklahoma has become more prevalent, and in a field study in Stillwater, a 21\% yield loss of wheat has been reported due to tan spot (Kader et al. 2009). The fungus has a sexual stage to its life cycle, which occurs on wheat residue (De Wolf et al. 1998). Shifting cultivation practices from clean tillage to a no-till system, which leaves residue in the field, is favorable for the survival, sexual recombination, and seasonal carry-over of this fungus (Bockus and Classen 1992; Baily 1996).

Variability within plant pathogens is a major problem in achieving disease control, and knowledge of variability within a pathogen species is essential for developing sustainable management practices. $P$. tritici-repentis is able to induce two distinct types of symptoms (necrosis and/or chlorosis) on wheat leaves (Lamari and Bernier 1989). This fungus is classified into eight races based on the necrosis and/ or chlorosis symptoms on wheat differentials (Andrie et al. 2007). Race 1 is the most prevalent in the USA, although 
other races (race 2 and 3 ) are reported occasionally (Ali and Francl 2003). In Canada, race 1 and 2 are predominant although race 3 is also reported (MacLean et al. 2017). As the presence of races of this fungus is a problem in wheatgrowing areas, identification of genes to employ a general or race-nonspecific resistance to tan spot in wheat has been emphasized (Faris et al. 2020). Significant research has been accomplished on the identification of quantitative trait loci conferring resistance to tan spot in wheat (Kariyawasam et al. 2018; Singh et al. 2019; Kokhmetova et al. 2020; Phuke et al. 2020).

Measuring the genetic relationship between pathogen isolates based on isolate virulence is often difficult to accomplish because complex host-pathogen-environment interactions affect disease development. Thus, employment of molecular tools is useful and reliable in determining the genetic variability of a species at the genomic level. $P$. tritici-repentis is one of the most extensively studied fungi at the genomic level (Ciuffetti et al. 2014). Researchers have used different molecular markers to study variability in $P$. tritici-repentis or related species, such as, rapid amplified polymorphic DNA (RAPD), inter simple sequence repeats (ISSR), internal transcribed spacer (ITS) sequence analysis, restriction fragment length polymorphism (RFLP) and simple sequence repeats (Faris et al. 1997; Stevens et al. 1998; Santos et al. 2002; Friesen et al. 2005; Singh and Hughes 2006; Aboukhaddour et al. 2011). Amplified fragment length polymorphism (AFLP) is a polymerase chain reaction (PCR)-based marker that is highly reproducible and has been used to estimate genetic relationship in different species of fungi (Vos et al. 1995; Majer et al. 1996; O'Neill et al. 1997; Garzon et al. 2005; Hielmann et al. 2006; Serenius et al. 2007). AFLP was also applied to study population genetic structure of $P$. tritici-repentis isolates (Friesen et al. 2005; Leisova et al. 2008). To date, elucidation of the genetic relationships in P. tritici-repentis isolates from Oklahomais lacking. The objectives of this study were to investigate race(s), disease symptoms and to reveal genetic relationship in P. tritici-repentis isolates collected over three decades from winter wheat in Oklahoma.

\section{Materials and methods}

\section{Fungal isolates}

The study was carried out at the Small Grain Pathology Lab at Oklahoma State University from 2008 to 2009 using 17 isolates of $P$. tritici-repentis, derived from single ascospores or single conidia, collected over three decades (the 1980s, 1990s and 2000s) from winter wheat in Oklahoma (Table 1). Isolates were stored in liquid nitrogen for long-term storage. When needed, isolates were removed
Table 1 Seventeen isolates of tan spot fungus Pyrenophora triticirepentis collected from several counties in Oklahoma and thirteen cultivars of winter wheat included in the study

\begin{tabular}{llll}
\hline Isolates & Initial propagule & County & Wheat cultivars \\
\hline OKA1 $(1983)^{\mathrm{b}}$ & Ascospore & Garfield & Billings \\
OKA2 (1983) & Ascospore & Garfield & Chisholm \\
OKD1 (1983) & Ascospore & Blaine & Deliver \\
OKD2 (1983) & Ascospore & Blaine & Duster \\
OKD3 (1983) & Ascospore & Blaine & Endurance \\
OKD4 (1983) & Ascospore & Blaine & Jagger \\
OKD5 (1983) & Ascospore & Blaine & Karl 92 \\
RBB6 (1996) & Ascospore & Kay & OK Bullet \\
GYA3 (1996) & Ascospore & Texas & Okfield \\
El Reno (2005) & Conidia & Canadian & OK Rising \\
Guymon (2006) & Conidia & Texas & Pete \\
Cherokee (2006) & Conidia & Cherokee & Tam 105 \\
OK-06-1 (2006) & Ascospore & Payne & Triumph 64 \\
OK-06-2 (2006) & Ascospore & Payne & \\
OK-06-3 (2006) & Ascospore & Payne & \\
Atoka (2007) & Conidia & Atoka & \\
Kiowa (2007) & Conidia & Pittsburg & \\
\hline
\end{tabular}

${ }^{a}$ All wheat cultivars are Oklahoma State University releases except for Jagger (Kansas State University) and Tam 105 (Texas A\&M University). Source of all wheat cultivars was the Oklahoma Foundation Seed Stocks, Stillwater, OK

${ }^{\mathrm{b}}$ Year of collection in parenthesis

${ }^{\mathrm{c} O K D} 4$ did not produce conidia on media and was not included in race studies in Table 2

from liquid nitrogen and were grown on potato dextrose agar (PDA) (200 g potato, $20 \mathrm{~g}$ dextrose, $15 \mathrm{~g}$ agar in $1 \mathrm{~L}$ water). Isolates were grown on PDA, and were maintained at $4{ }^{\circ} \mathrm{C}$ in the dark during the experiment.

\section{Inoculum preparation}

Conidia were produced by each isolate following the procedure of Raymond et al. (1985). A 5-mm diameter mycelial plug, excised with a sterilized cork borer from the edge of an actively growing isolate on fresh PDA, was removed and placed on clarified V8 (CV8) juice agar $(150 \mathrm{ml} \mathrm{V8}$ juice, $3 \mathrm{~g} \mathrm{CaCO}_{3}, 15 \mathrm{~g}$ agar, $850 \mathrm{ml}$ water) in $90-\mathrm{mm}$ petri plates were maintained in an incubator (Percival I-36LL, Boone, IA) at $23{ }^{\circ} \mathrm{C}$ in the dark for 5 days. About 10 drops of sterile water were added and mycelia were matted down using a sterile bent glass rod. Plates were then incubated for $12 \mathrm{~h}$ at $23{ }^{\circ} \mathrm{C}$ with cool-white fluorescent tubes $(40 \mathrm{~W}, 30$ $\mu \mathrm{Es}^{-1} \mathrm{~m}^{-1}$ ) to produce conidiophores followed by $12 \mathrm{~h}$ dark at $16{ }^{\circ} \mathrm{C}$ to induce conidia production. Conidia were washed from the plate into a beaker using a stream of sterile water. Conidia were adjusted to 2000 per $\mathrm{ml}$ before inoculation. 


\section{Race identification}

Races were determined based on necrosis and/or chlorosis model on wheat differentials (Andrie et al. 2007). Wheat differential lines 6B662, Glenlea, 6B365, and Salamouni were used according to Ali and Francl (2003). Four seeds of each wheat differential were planted separately in plastic containers $(15 \mathrm{~cm} \times 3.75 \mathrm{~cm})$ filled with Ready-Earth soil (Sun Gro., Bellevue, WA). Using an atomizer (DeVilbiss Co. Somerset, PA), seedlings with two leaves fully expanded were inoculated with the conidial suspension (2000 conidia/ $\mathrm{ml}$ ) of each isolate until incipient run-off following the procedure of Rodriguez and Bockus (1996). Inoculated plants were allowed to dry for $30 \mathrm{~min}$ so that conidia would adhere to leaves and then were placed in a mist chamber for $48 \mathrm{~h}$. Inoculated plants then were placed on a lab bench at $21-23{ }^{\circ} \mathrm{C}$ following a cycle of $14 \mathrm{~h}$ light $\left(510 \mu \mathrm{Es}^{-1} \mathrm{~m}^{-1}\right)$ and $10 \mathrm{~h}$ dark. Seven days after inoculation, symptoms produced by each isolate on the wheat differentials were rated on a scale of 1-5 based on lesion type, where $1=$ small, dark brown to black spots without any surrounding chlorosis or tan necrosis (resistant), $2=$ small, dark brown to black spots with very little chlorosis or tan necrosis (resistant), $3=$ small dark brown to black spots completely surrounded by a distinct chlorotic or necrotic ring, lesions not coalescing (susceptible), $4=$ spots completely surrounded by chlorotic or necrotic zones, lesion coalescing (susceptible), $5=$ spots may not be distinguishable, lesions coalescing and spread over leaf (susceptible) (Lamari and Bernier 1989). The bottom 2nd leaf from all four seedlings of each differential was rated per isolate. Isolate OKD4 did not produce conidia so was not included in the study.

\section{Symptom variability}

To study variability in symptoms, 13 wheat cultivars and 12 isolates were used (Table 3). Seedlings of wheat cultivars were raised, and inoculum of each isolate was prepared as described earlier. At the three-leaf stage, four seedlings of each cultivar were inoculated with 2000 conidia/ml until incipient run-off and then maintained as described earlier. Disease symptoms produced by each isolate (necrosis and/or chlorosis) were recorded visually five days after inoculation from the bottom 2 nd leaf.

\section{DNA extraction and ITS sequence}

Four day-old fungal mycelia on PDA plates were ground into a fine powder using a mortar and pestle and liquid nitrogen. Genomic DNA was extracted from $\sim 0.25 \mathrm{~g}$ mycelia powder of each isolate and the purity of DNA was examined on agarose gel following the salt-extraction method (Aljanabi and Martinez 1997).
Nuclear internal transcribed spacer (ITS) regions (ITS1- 5.8S rDNA- ITS2) were amplified by polymerase chain reaction (PCR) using ITS4 and ITS5 primers (White et al. 1990). Electrophoresis of amplified ITS region was performed in a $1 \%$ agarose gel. DNA was stained with ethidium bromide and visualized under UV light. Amplified products were purified using Purelink ${ }^{\mathrm{TM}}$ PCR Purification Kit (Invitrogen, Carslbad, CA). The ITS region from each isolate was sequenced at the Oklahoma State University (OSU) Core Facility, and the sequences were compared with P. tritici-repentis GenBank accessions in the NCBI database (www.ncbi.nih.gov) using the Basic Local Alignment Search Tool (BLAST).

\section{AFLP analysis}

AFLP analysis was performed by using an AFLPTM Microbial Fingerprinting kit following manufacturer's instruction (Applied Biosystems, Foster city, CA). In brief, steps in the AFLP performed were DNA digestion by EcoR 1 and $M s e 1$ restriction enzymes, adapter ligation, pre-amplification and selective amplification. The selective amplified products were separated by capillary electrophoresis by an ABI 3730 DNA Analyzer with ROX 500 as internal standard size (Applied Biosystems, Foster city, CA). The chromatograms were converted into a binary data matrix as presence (1) or absence ( 0 ) of an allele using GeneMapper 4.0 software (Applied Biosystems, CA) calibrated against 75-500 bp DNA size standards. Thus, a total set of binary data was generated for all 13 primer combinations across all 17 isolates.

Genetic diversity (DI) among the isolates for each primer combination was determined using the POPGENE software (version 1.32, University of Alberta, Edmonton, Canada) as $\mathrm{DI}=1-\sum \mathrm{P}^{2} i$, where $\mathrm{P}^{2} i$ is the frequency of $i$ th allele at a locus in a population (Nei 1978). A principal component analysis (PCA) was carried out using the PRINCOMP procedure of SAS 9.2 (SAS Institute, Cary, NC) to determine genetic relationship among isolates.

\section{Results}

\section{Race structure}

All isolates except one (El Reno) were identified as race 1 based on the symptoms produced on the wheat differential set (1-5 scale; 1-2 resistant, 3-5 susceptible) (Table 2). No disease symptoms other than dark brown to black spots were induced by El Reno, which therefore was considered as race 4. 
Table 2 Reaction of isolates on four wheat differential varieties and identification of races in Pyrenophora tritici-repentis collected from 1980s, 1990s and 2000s in Oklahoma

\begin{tabular}{|c|c|c|c|c|c|}
\hline \multirow[t]{2}{*}{ Isolates } & \multicolumn{4}{|c|}{ Wheat differential } & \multirow[t]{2}{*}{ Race $^{b}$} \\
\hline & $6 \mathrm{~B} 662$ & Glenlea & $6 \mathrm{~B} 365$ & Salamouni & \\
\hline \multicolumn{6}{|l|}{$1980 \mathrm{~s}$} \\
\hline OKA1 & $1 \mathrm{R}^{\mathrm{a}}$ & $4 \mathrm{~N}$ & $5 \mathrm{C}$ & $1 \mathrm{R}$ & Race 1 \\
\hline OKA2 & $1 \mathrm{R}$ & $3 \mathrm{~N}$ & $5 \mathrm{C}$ & $1 \mathrm{R}$ & Race 1 \\
\hline OKD1 & $2 \mathrm{R}$ & $5 \mathrm{~N}$ & $5 \mathrm{C}$ & $1 \mathrm{R}$ & Race 1 \\
\hline OKD2 & $2 \mathrm{R}$ & $4 \mathrm{~N}$ & $5 \mathrm{C}$ & $1 \mathrm{R}$ & Race 1 \\
\hline OKD3 & $1 \mathrm{R}$ & $4 \mathrm{~N}$ & $5 \mathrm{C}$ & $1 \mathrm{R}$ & Race 1 \\
\hline OKD5 & $1 \mathrm{R}$ & $3 \mathrm{~N}$ & $3 \mathrm{C}$ & $1 \mathrm{R}$ & Race 1 \\
\hline \multicolumn{6}{|l|}{$1990 s$} \\
\hline RBB6 & $1 \mathrm{R}$ & $5 \mathrm{~N}$ & $5 \mathrm{C}$ & $1 \mathrm{R}$ & Race 1 \\
\hline GYA3 & $1 \mathrm{R}$ & $3 \mathrm{~N}$ & $4 \mathrm{C}$ & $1 \mathrm{R}$ & Race 1 \\
\hline \multicolumn{6}{|l|}{$2000 s$} \\
\hline El Reno & $1 \mathrm{R}$ & $1 \mathrm{R}$ & $1 \mathrm{R}$ & $1 \mathrm{R}$ & Race 4 \\
\hline Guymon & $1 \mathrm{R}$ & $5 \mathrm{~N}$ & $5 \mathrm{C}$ & $1 \mathrm{R}$ & Race 1 \\
\hline Cherokee & $2 \mathrm{R}$ & $4 \mathrm{~N}$ & $5 \mathrm{C}$ & $1 \mathrm{R}$ & Race 1 \\
\hline OK-06-1 & $1 \mathrm{R}$ & $4 \mathrm{~N}$ & $5 \mathrm{C}$ & $2 \mathrm{R}$ & Race 1 \\
\hline OK-06-2 & $1 \mathrm{R}$ & $5 \mathrm{~N}$ & $5 \mathrm{C}$ & $2 \mathrm{R}$ & Race 1 \\
\hline OK-06-3 & $1 \mathrm{R}$ & $5 \mathrm{~N}$ & $5 \mathrm{C}$ & $1 \mathrm{R}$ & Race 1 \\
\hline Atoka & $2 \mathrm{R}$ & $5 \mathrm{~N}$ & $5 \mathrm{C}$ & $2 \mathrm{R}$ & Race 1 \\
\hline Kiowa & $1 \mathrm{R}$ & $4 \mathrm{~N}$ & $5 \mathrm{C}$ & $1 \mathrm{R}$ & Race 1 \\
\hline
\end{tabular}

${ }^{a}$ Lesion type on a 1-5 scale, where $1=$ small, dark brown to black spots without any surrounding chlorosis or tan necrosis (resistant), $2=$ small, dark brown to black spots with very little chlorosis or tan necrosis (resistant), $3=$ small dark brown to black spots completely surrounded by a distinct chlorotic or necrotic ring, lesions not coalescing (susceptible), $4=$ spots completely surrounded by chlorotic or necrotic zones, lesion coalescing (susceptible), $5=$ spots may not be distinguishable, lesions coalescing and spread over leaf (susceptible) (Lamari and Bernier 1989)

$\mathrm{R}=$ resistant, $\mathrm{N}=$ necrosis, $\mathrm{C}=$ chlorosis. Decade of collection is in bold

${ }^{b}$ Races identified based on symptoms on leaf as necrosis and/or chlorosis (Andrie et al. 2007)

\section{Disease symptoms}

All 12 isolates tested were pathogenic and varied widely in symptoms induced on wheat cultivars (Table 3). Single isolates, for example isolate OKA1, were able to produce necrosis with a yellow halo $(\mathrm{N})$, necrosis with extended chlorosis (NC) or only chlorosis extended over the leaf (C) on wheat cultivars. Similarly isolates also produced a range of symptoms on a cultivar. Necrosis was the dominant symptom $(56.41 \%)$ followed by necrosis with extended chlorosis $(32.05 \%)$ and chlorosis $(11.54 \%)$ from the overall combination of 12 cultivars and 13 isolates.

\section{Genetic variability}

Results from the AFLP analysis are presented in Table 4. Using 13 primer combinations all 17 isolates of $P$. triticirepentis yielded a total of 494 alleles of which 285 were polymorphic. On an average each primer combination produced 38 alleles of which $\sim 22$ were polymorphic. The EcoR1-AA and Mse1-C combination yielded the highest number of alleles of 70, while the EcoR1-AT and Mse1CAG combination produced the fewest number of alleles of 16. The highest number of polymorphic alleles (44 out of 70) was detected by the EcoR1-AA and Mse1-C combination. The percentage of polymorphism ranged from 26.42 to $100 \%$, with an average of $57.69 \%$. An overall genetic diversity among the isolates was 0.252 , with a range of variation from 0.104 to 0.394 for the primer combinations. All the isolates formed one large group by the principal component analysis (PCA) (Fig. 1). In PCA, the first, second and third PC explained $37.3 \%, 8.02 \%$ and $6.45 \%$ of the total variability, respectively.

\section{Discussion}

In Oklahoma, race 1 was the predominant race present in the three decades of collection time. In this study, 15 out of 16 isolates were race 1 , and one was race 4 (Table 2), which is in agreement with previous research. For example, Ali and Francl (2003) tested 22 isolates collected from wheat in the southern Great Plains of the USA and reported that 21 of 22 isolates were race 1 and a single isolate was race 4 . In a study with a global collection of $P$. tritici-repentis populations, five isolates included from Oklahoma were determined as race 1 (Friesen et al. 2005). Race 1 is the most virulent and fit race due to the presence of two toxin genes (necrosis and chlorosis). One of the drawbacks of modern wheat monoculture is the lack of genetic diversity among cultivars. Thus, the genetic base in wheat for resistance to tan spot is narrow which favors this pathogen, and as indicated by Ali and Francl (2003), the predominance of race 1 may be due to the lack of selection pressure on this fungus because most of the wheat cultivars are susceptible. Race 4 has also been isolated from alternative non-cereal grasses (Ali and Francl 2003). It is suspected that isolate El Reno might have come into wheat from a non-cereal host. Race 4 likely would not be persistent in wheat because it would not compete as well as the more virulent races.

The presence of specific races of a pathogen can have practical implications on plant disease management studies and on breeding for resistance. For example, in a management study involving tan spot, using a $P$. tritici-repentis race common to an area would be most meaningful, and resistance breeding for a disease such as tan spot should be 
Table 3 Different symptoms produced by 13 wheat cultivar in response to 12 isolates of Pyrenophora tritici-repentis collected from Oklahoma winter wheat fields

\begin{tabular}{|c|c|c|c|c|c|c|c|c|c|c|c|c|c|}
\hline \multirow[t]{2}{*}{ Isolates } & \multicolumn{13}{|c|}{ Wheat cultivars } \\
\hline & Billings & Chisholm & Deliver & Duster & Endurance & Jagger & Karl 92 & OK Bullet & Okfield & OK Rising & Pete & TAM 105 & Triumph 64 \\
\hline OKA1 & $\mathrm{NC}$ & $\mathrm{N}$ & $\mathrm{N}$ & $\mathrm{N}$ & $\mathrm{C}$ & $\mathrm{N}$ & $\mathrm{N}$ & $\mathrm{N}$ & $\mathrm{N}$ & $\mathrm{N}$ & $\mathrm{N}$ & $\mathrm{NC}$ & $\mathrm{N}$ \\
\hline OKA2 & $\mathrm{NC}$ & $\mathrm{N}$ & $\mathrm{N}$ & $\mathrm{N}$ & $\mathrm{NC}$ & $\mathrm{N}$ & $\mathrm{N}$ & $\mathrm{N}$ & $\mathrm{N}$ & $\mathrm{N}$ & $\mathrm{N}$ & $\mathrm{N}$ & $\mathrm{N}$ \\
\hline OKD1 & $\mathrm{NC}$ & $\mathrm{N}$ & $\mathrm{NC}$ & $\mathrm{N}$ & $\mathrm{C}$ & $\mathrm{N}$ & $\mathrm{N}$ & $\mathrm{N}$ & $\mathrm{N}$ & $\mathrm{N}$ & $\mathrm{N}$ & $\mathrm{NC}$ & $\mathrm{N}$ \\
\hline OKD2 & $\mathrm{NC}$ & $\mathrm{NC}$ & $\mathrm{NC}$ & $\mathrm{N}$ & $\mathrm{C}$ & $\mathrm{N}$ & $\mathrm{N}$ & $\mathrm{N}$ & $\mathrm{N}$ & $\mathrm{N}$ & $\mathrm{N}$ & $\mathrm{N}$ & $\mathrm{N}$ \\
\hline OKD5 & $\mathrm{C}$ & $\mathrm{N}$ & $\mathrm{NC}$ & $\mathrm{N}$ & $\mathrm{C}$ & $\mathrm{N}$ & $\mathrm{NC}$ & $\mathrm{N}$ & $\mathrm{N}$ & $\mathrm{N}$ & $\mathrm{N}$ & $\mathrm{NC}$ & $\mathrm{N}$ \\
\hline RBB6 & $\mathrm{C}$ & $\mathrm{N}$ & $\mathrm{NC}$ & $\mathrm{NC}$ & $\mathrm{C}$ & $\mathrm{NC}$ & $\mathrm{NC}$ & $\mathrm{NC}$ & $\mathrm{NC}$ & $\mathrm{N}$ & $\mathrm{N}$ & $\mathrm{NC}$ & $\mathrm{NC}$ \\
\hline Cherokee & $\mathrm{C}$ & $\mathrm{N}$ & $\mathrm{NC}$ & $\mathrm{NC}$ & $\mathrm{C}$ & $\mathrm{N}$ & $\mathrm{NC}$ & $\mathrm{N}$ & $\mathrm{NC}$ & $\mathrm{NC}$ & $\mathrm{N}$ & $\mathrm{N}$ & $\mathrm{NC}$ \\
\hline Guymon & $\mathrm{C}$ & $\mathrm{NC}$ & $\mathrm{NC}$ & $\mathrm{NC}$ & $\mathrm{C}$ & $\mathrm{N}$ & $\mathrm{NC}$ & $\mathrm{N}$ & $\mathrm{N}$ & $\mathrm{NC}$ & $\mathrm{N}$ & $\mathrm{NC}$ & $\mathrm{N}$ \\
\hline OK-06-1 & $\mathrm{C}$ & $\mathrm{NC}$ & $\mathrm{NC}$ & $\mathrm{N}$ & $\mathrm{C}$ & $\mathrm{N}$ & $\mathrm{NC}$ & $\mathrm{N}$ & $\mathrm{N}$ & $\mathrm{N}$ & $\mathrm{N}$ & $\mathrm{NC}$ & $\mathrm{NC}$ \\
\hline OK-06-3 & $\mathrm{C}$ & $\mathrm{N}$ & $\mathrm{NC}$ & $\mathrm{NC}$ & $\mathrm{C}$ & $\mathrm{NC}$ & $\mathrm{N}$ & $\mathrm{N}$ & $\mathrm{N}$ & $\mathrm{N}$ & $\mathrm{N}$ & $\mathrm{NC}$ & $\mathrm{NC}$ \\
\hline Atoka & $\mathrm{NC}$ & $\mathrm{N}$ & $\mathrm{NC}$ & $\mathrm{N}$ & $\mathrm{C}$ & $\mathrm{N}$ & $\mathrm{N}$ & $\mathrm{N}$ & $\mathrm{N}$ & $\mathrm{NC}$ & $\mathrm{N}$ & $\mathrm{NC}$ & $\mathrm{N}$ \\
\hline Kiowa & $\mathrm{C}$ & $\mathrm{N}$ & $\mathrm{NC}$ & $\mathrm{N}$ & $\mathrm{C}$ & $\mathrm{N}$ & $\mathrm{N}$ & $\mathrm{N}$ & $\mathrm{N}$ & $\mathrm{N}$ & $\mathrm{N}$ & $\mathrm{NC}$ & $\mathrm{NC}$ \\
\hline
\end{tabular}

Cultivars Billings and Endurance produced extended chlorosis with little necrosis

$N$ Necrosis with yellow hallow, $C$ Chlorosis extended over leaf, $N C$ Both necrosis and chlorosis, usually necrosis with little extended chlorosis

Table 4 Genetic variability in 17 isolates of Pyrenophora triticirepentis following amplified fragment length polymorphism (AFLP) analysis using 13 primer combinations

\begin{tabular}{llllll}
\hline EcoR1- & Mse1- & Total allele & $\begin{array}{l}\text { Poly- } \\
\text { morphic } \\
\text { allele }\end{array}$ & $\begin{array}{l}\text { Percent } \\
\text { polymor- } \\
\text { phism }\end{array}$ & $\begin{array}{l}\text { Genetic } \\
\text { diversity }\end{array}$ \\
\hline AA & C & 70 & 44 & 62.86 & 0.204 \\
AA & CA & 53 & 14 & 26.42 & 0.104 \\
AA & CG & 57 & 32 & 56.14 & 0.196 \\
AA & GC & 24 & 23 & 95.83 & 0.394 \\
AC & CA & 30 & 15 & 50.00 & 0.158 \\
AG & C & 57 & 31 & 54.39 & 0.233 \\
AG & GA & 21 & 19 & 90.48 & 0.374 \\
AT & C & 51 & 25 & 49.02 & 0.193 \\
AT & CA & 20 & 12 & 60.00 & 0.256 \\
AT & CAC & 19 & 19 & 100.00 & 0.397 \\
AT & CAG & 16 & 16 & 100.00 & 0.397 \\
TA & C & 27 & 12 & 44.44 & 0.188 \\
TG & C & 49 & 23 & 46.94 & 0.183 \\
Total & & 494 & 285 & - & - \\
Average & & 38 & 21.92 & 57.69 & 0.252 \\
\hline
\end{tabular}

focused to select for resistance against the most prevalent races in the area.

Isolates varied considerably in producing necrosis and/or chlorosis symptoms on wheat cultivars (Table 3 ). For example, isolate OKA1 produced necrosis on cultivar Chisholm but produced chlorosis on cultivar Endurance. A cultivar also produced different symptoms in reaction to isolates. This suggests that collection of isolates should be symptom or cultivar independent. In studying wheat-Ptr interaction, other researchers also found that an isolate is able to induce necrosis and chlorosis symptoms on different wheat cultivars (Lamari and Bernier 1991). Conversely, a range of symptoms are produced on a single cultivar when inoculated by different isolates (Moreno et al. 2008). It might be a cultivar has its own genetic and physiological effect in producing disease symptom(s).

AFLP data demonstrated only a slight genetic diversity $(0.252)$ among the isolates (Table 4). This finding is consistent with other marker studies of $P$. tritici-repentis populations where primer combinations revealed a range of $0-0.47$ genetic diversity within 97 isolates, with an average genetic diversity of about 0.1 (Friesen et al. 2005). Using AFLP, Leisova et al. (2008) also observed a low genetic diversity (0.096) among 100 isolates of $P$. tritici-repentis in the Czech Republiccollected during 1998-2005. The reasons for genetic diversity in P. tritici-repentis could be due to sexual recombination or vegetative compatibility among isolates (Singh and Hughes 2006; Moreno et al 2008). However, as P. tritici-repentis is a homothallic fungus, sexual recombination may not contribute to a significant extend in genetic variation as the male and female gametes are coming from the same thallus. Thus, although the isolates were collected over three decades in this study, a greater genetic variation was not observed among the isolates.

Principle component analysis (PCA) revealed no grouping among the isolates of $P$. tritici-repentis, thus, the isolates used in this study are likely derived from a common lineage. In a study with 97 isolates of $P$. tritici-repentis, no genetic grouping was identified by AFLP marker study (Friesen et al. 2005). In PCA, a high value of $P C$ is able to explain the greatest amount of variation (Hielmann et al. 2006). In this 
A

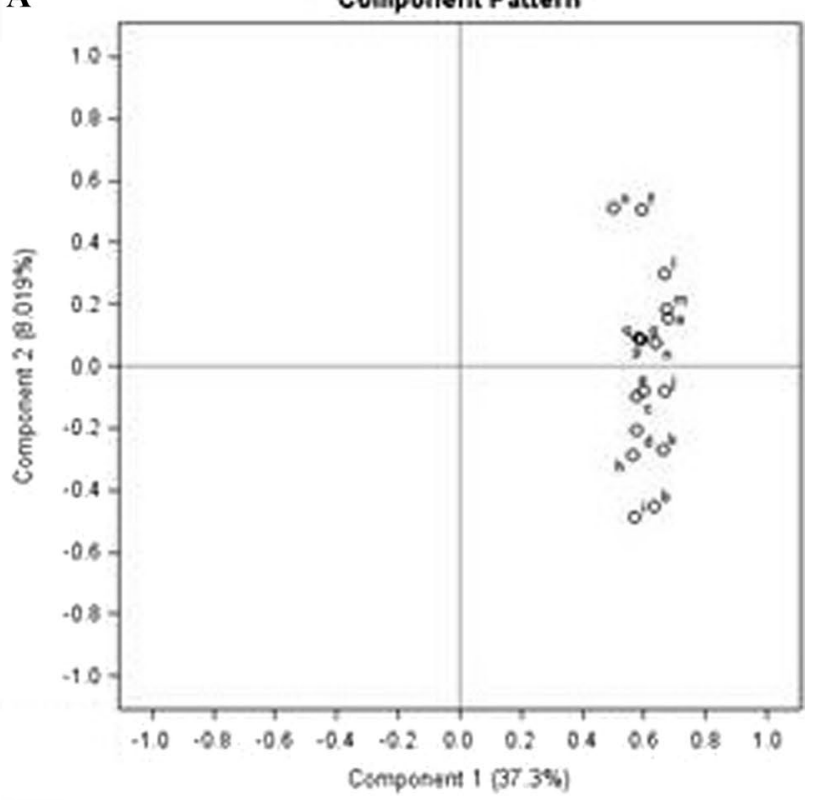

B

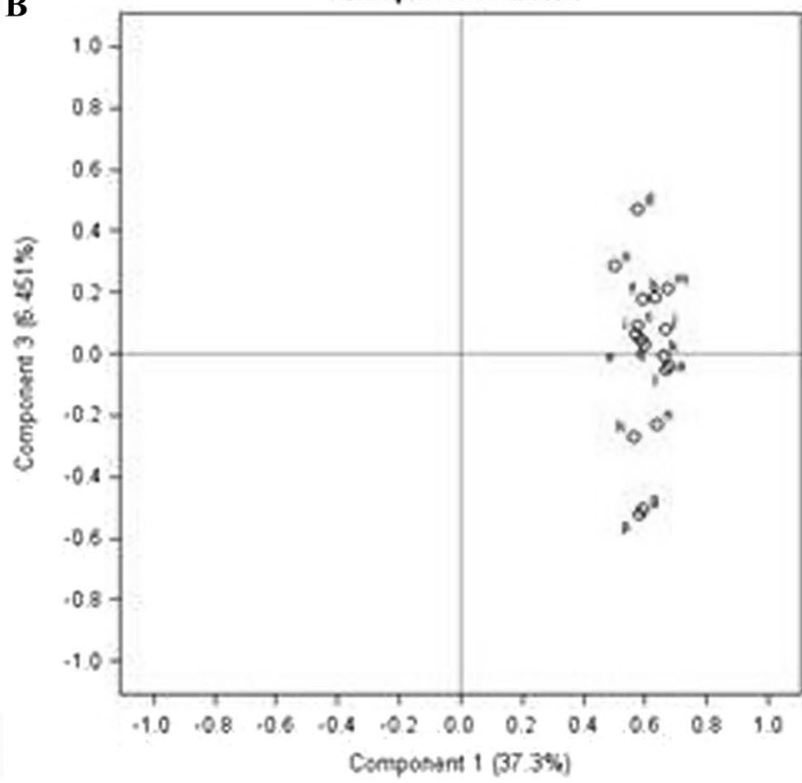

Fig. 1 Principal component analysis based on amplified fragment length polymorphism (AFLP) for 17 isolates of Pyrenophora triticirepentis collected from winter wheat in Oklahoma. Principal component values grouped the isolates in one group (A and $\mathrm{B}$ )

study, PC1 explained the highest variability (37.3\%) of the total variation and put all the isolates in one group (Fig. 1) which is in agreement with other researchers. In an AFLP analysis with 100 isolates of $P$. tritici-repentis, Leisova et al. (2008) also found that high PC value fit all isolates into one large group. Although isolate El-Reno was race 4, it did not affect the clustering. This is because variation in a single virulence gene determines a race, while in this study, the relationship among the isolates was determined from the variability in whole genome by AFLP analysis.

Race 1 was the predominant race in Oklahoma wheat fields and produced a range of tan spot symptoms. Results in this study also indicate that the isolates originated from a single lineage, and other characteristics such as growth rate, sporulation and virulence that can affect disease epidemiology should be considered in selecting selection of $P$. tritici-repentis isolates for use in wheat resistance screening for tan spot management. Regular monitoring and virulence testing of this pathogen would also benefit tan spot management. This study reveals that a complete understanding of variability in the population of $P$. tritici-repentis is critical to resistance screening of wheat cultivars. Knowledge on the pathogen variability would facilitate resistance breeding programs and the development of management practices, for example, selection of fungicides. A representative isolate from different groups or lineages, if any, should be included in the screening of cultivars to deploy a wider resistance to $\tan$ spot.

Acknowledgements Funding by the Oklahoma Agricultural Experimental Station and the Oklahoma Wheat Research Foundation is gratefully acknowledged. S. Ali at North Dakota State University provided seeds of wheat differentials. We thank C. Garzon for allowing us working in her lab and for useful discussion and advice. Technical assistance from L. Whiteworth at OSU DNA core facility and help from M. Arif is acknowledged.

Open Access This article is licensed under a Creative Commons Attribution 4.0 International License, which permits use, sharing, adaptation, distribution and reproduction in any medium or format, as long as you give appropriate credit to the original author(s) and the source, provide a link to the Creative Commons licence, and indicate if changes were made. The images or other third party material in this article are included in the article's Creative Commons licence, unless indicated otherwise in a credit line to the material. If material is not included in the article's Creative Commons licence and your intended use is not permitted by statutory regulation or exceeds the permitted use, you will need to obtain permission directly from the copyright holder. To view a copy of this licence, visit http://creativecommons.org/licenses/by/4.0/.

\section{References}

Aboukhaddour R, Coultier S, Lamari L, Strelkov SE (2011) Simple sequence repeats and diversity of globally distributed population of Pyrenophora tritici-repentis. Can J Plant Pathol 33:389-399. https://doi.org/10.1080/07060661.2011.590821

Ali S, Francl LJ (2003) Population race structure of Pyrenophora tritici-repentis prevalent on wheat and noncereal grasses in the Great Plaines. Plant Dis 87:418-422. https://doi.org/10.1094/ PDIS.2003.87.4.418

Aljanabi SM, Martinez I (1997) Universal and rapid salt-extraction of high quality genomic DNA for PCR-based techniques. Nucleic Acids Res 25:4692-4693. https://doi.org/10.1093/nar/25.22.4692

Andrie RM, Pandelova I, Ciuffetti LM (2007) A combination of phenotypic and genotypic characterization strengthens Pyrenophora 
tritici-repentis race identification. Phytopathology 97:694-701. https://doi.org/10.1094/PHYTO-97-6-0694

Baily KL (1996) Diseases under conservation tillage system. Can J Plant Sci 76:635-639. https://doi.org/10.4141/cjps96-113

Bockus WW, Classen MM (1992) Effect of crop rotation and residue management practices on severity of tan spot of winter wheat. Plant Dis 76:633-636. https://doi.org/10.1094/PD-76-0633

Bockus WW, Bowden RL, Hunger RM, Morrill WL, Murray TD, Smiley RW (2010) Compendium of Wheat Diseases and Pests, 3rd edn. APS Press. The American Phytopathological Society, St. Paul, MN, USA, p 171

Ciuffetti LM, Manning VA, Pandelova I, Faris JD, Friesen TL, Strelkov SE, WeberGoodwin GLGB, Wolpert TJ, Figueroa M (2014) Pyrenophora tritici-repentis: A plant pathogenic fungus with global impact. In: Dean RA, Lichen-Park A, Koli C (eds) Genomics of plant associated fungi: Monocot pathogens. Springer, Berlin Heidelberg, pp 1-40

De Wolf ED, Effertz RJ, Ali S, Francl LJ (1998) Vistas of tan spot research. Can J Plant Pathol 20:349-370. https://doi.org/10.1080/ 07060669809500404

Faris JD, Anderson JA, Francl LJ, Jordahl JG (1997) RLFP mapping of resistance to chlorosis induction by Pyrenoiphora tritici-repentis. Theor Appl Genet 94:98-103. https://doi.org/10.1007/s001220050 387

Faris JD, Overlander ME, Kariyawasam GK, Carter A, Liu Z (2020) Identification of a major dominant gene for race-nonspecific tan spot resistance in Emmer wheat. Theor Appl Genet 133:829-841. https:// doi.org/10.1007/s00122-019-03509-80

Francl LJ, Krupinsky JM, McMullen MP (1992) Advances in tan spot research. Proceedings of the 2nd international tan spot workshop. North Dakota State University, Fargo, ND. pp 142.

Friesen TL, Ali S, Klein KK, Rasmussen JB (2005) Population genetic analysis of a global collection of Pyrenophora tritici-repentis, causal agent of tan spot of wheat. Phytopathology 95:1144-1150. https:// doi.org/10.1094/PHYTO-95-1144

Friskop A, Liu Z (2016) Fungal leaf spot diseases of wheat: Tan spot, Septoria/Stagonospora nodorum blotch and Septoria tritici blotch. Extension bulletin no. 1249. North Dakota State University, Fargo, ND. pp 4

Garzon CD, Geiser DM, Moorman GW (2005) Diagnosis and population analysis of Pythium species using AFLP fingerprinting. Plant Dis 89:81-89. https://doi.org/10.1094/PD-89-0081

Hielmann LJ, Nitzan N, Johnson DA, Pasche JS, Doetkott C, Gudmestad NC (2006) Genetic variability in the potato pathogen Colletotrichum coccodes as determined by amplified fragment length polymorphism and vegetative compatibility group analysis. Phytopathology 96:1097-1107. https://doi.org/10.1094/PHYTO-96-1097

Hunger RM, Brown DA (1987) Colony color, growth, sporulation, fungicide sensitivity and pathogenicity of Pyrenophora tritici-repentis. Plant Dis 71:907-910. https://doi.org/10.1094/PD-71-0907

Kader KA, Hunger RM, Edwards JT (2009) Characterization of three isolates of Pyrenophora tritici-repentis collected from winter wheat in Oklahoma in 1983, 1996, and 2006. Phytopathology 99:S60

Kariyawasam GK, Hussain W, Easterly A, Guttieri M, Belamkar V, Poland J, Venegas J, Baenziger S, Marais F, Rasmussen JB, Liu Z (2018) Identification of quantitative trait loci conferring resistance to tan spot in a biparental population derived from two Nebraska hard red winter wheat cultivars. Molec Breeding 38:140. https://doi.org/ 10.1007/s11032-018-0901-3

Kokhmetova A, Sehgal D, Ali S, Atishova M, Kumarbayeva M, Leonova I, Dreisigacker S (2020) Genome-wide association study of tan spot resistance in a hexaploid wheat collection from Kazakhstan. Front Genet. https://doi.org/10.3389/fgene.2020.581214

Lamari L, Bernier CC (1989) Evaluation of wheat lines and cultivars to tan spot (Pyrenophora tritici-repentis) based on lesion type. Can J Plant Pathol 11:49-56. https://doi.org/10.1080/07060668909501146
Lamari L, Bernier CC (1991) Wheat genotypes that develop both tan necrosis and extensive chlorosis in response to isolates of $\mathrm{Pyr}$ enophora tritici-repentis. Plant Dis 75:121-122. https://doi.org/10. 1094/PD-75-0121

Leisova L, Hanzalova A, Kucera L (2008) Genetic diversity of Pyrenophora tritici-repentis as revealed by AFLP analysis. J Plant Pathol 90:233-245 https://www.jstor.org/stable/41998500

MacLean DE, Aboukhaddour R, Tran VA, Askarin H, Strelkov SE, Turkington TK, Kutcher HR (2017) Race Characterization of Pyrenophora tritici-repentis and sensitivity to propiconazole and pyraclostrobin fungicides. Can J Plant Pathol 39:433-443. https://doi. org/10.1080/07060661.2017.1387178

Majer D, Mitchen R, Lewis BJ, Vos P, Oliver RP (1996) The use of AFLP fingerprinting for the detection of genetic variation in fungi. Mycol Res 100:1107-1111. https://doi.org/10.1016/S0953-7562(96) 80222-X

Moreno MV, Stenglein SA, Balatti PA, Perello AE (2008) Pathogenic and molecular variability among isolates of Pyrenophora tritici-repentis, causal agent of tan spot of wheat in Argentina. European J Plant Pathol 122:239-252. https://doi.org/10.1007/s10658-008-9277-2

NASS 2019. National Agricultural Statistical Service. United States Department of Agriculture. Washington D.C. (www.nass.usda. gov/ok)

Nei M (1978) Estimation of average heterozygosity and genetic distance from small number of individuals. Genetics 89:583-590 https:// www.genetics.org/content/89/3/583

O'Neill NR, van Berkum P, Lin JJ, Kuo J, Ude GN, Kenworthy W, Saunders JA (1997) Application of amplified restriction fragment length polymorphism for genetic characterization of Colletotrichum pathogens of alfalfa. Phytopathology 87:745-750. https://doi.org/10.1094/ PHYTO.1997.87.7.745

Phuke RM, He X, Juliana P, Bishnoi SK, Singh GP, Kabir MR, Roy KK, Joshi AK, Singh RP, Singh PK (2020) Association mapping of seedling resistance to tan spot (Pyrenophora tritici-repentis Race 1) in CIMMYT and South Asian wheat germplasm. Front Plant Sci 11:1039. https://doi.org/10.3389/fpls.2020.01309

Raymond PJ, Bockus WW, Norman BL (1985) Tan spot of winter wheat: procedures to determine host response. Phytopathology 75:686-690. https://doi.org/10.1094/Phyto-75-686

Rodriguez RW, Bockus WW (1996) Differences among isolates of Pyrenophora tritici-repentis in production of conidia on wheat leaves. Plant Dis 80:478-483. https://doi.org/10.1094/PD-80-0478

Santos AMPV, Matsumura ATS, Sand STVD (2002) Interspecific genetic diversity of Drechslera tritici-repentis as detected by random amplified polymorphic DNAanalysis. Genet Molec Biol 25:243-250. https://doi.org/10.1590/S1415-47572002000200020

Serenius M, Manninen O, Wallwork H, Williams K (2007) Genetic differentiation in Pyrenophora teres populations measured with AFLP markers. Mycol Res 111:213-223. https://doi.org/10.1016/j.mycres. 2006.11.009

Shabeer A, Bockus WW (1988) Tan spot effects on yield and yield components relative to growth stages in winter wheat. Plant Dis 72:599-602. https://doi.org/10.1094/PD-72-0599

Singh PK, Hughes GR (2006) Genetic similarity among isolates of Pyrenophora tritici-repentis, causal organism of tan spot of wheat. J Phytopathol 154:178-184. https://doi.org/10.1111/j.1439-0434. 2006.01083.x

Singh PK, Singh S, Deng Z, He X, Kehel Z, Singh RP (2019) Characterization of QTLs for seedling resistance to tan spot and septoria nodorum blotch in the PBW343/Kenya Nyangumi wheat recombinant inbred lines populations. Int J Mol Sci 20:5432. https://doi.org/ 10.3390/ijms20215432

Stevens EA, Blakemore EJA, Reeves JC (1998) Relationship among barley and oat infecting isolates of Pyrenophora spp. based on sequence of the internal transcribed spacer regions of ribosomal 
DNA. Molecular Plant Pathology On-line [http://www.bspp.org.uk/ mppol1998/1111stevens]

Vos P, Hogers R, Bleeker M, Reijer M, van de Lee T, Hornes M, Frizters A, Pot J, Peleman J, Kuiper M, Zabeau M (1995) AFLP: A new technique for DNAfingerprinting. Nucleic Acids Res 23:4407-4414. https://doi.org/10.1093/nar/23.21.4407

Wegulo SN, Klien RN, Harveson RM (2012) Tan spot of cereals. Extension bulletin no. G429. Univ. Nebraska, Lincoln, NE; pp 3
White TJ, Bruns T, Lee S, Taylor J (1990) Amplification and direct sequencing of fungal ribosomal DNA for phylogenetics. In: Innis MA, Gelfand DH, Sninsky JJ, White TJ (eds) PCR protocols: A guide to the methods and applications. Academic Press, San Diego, CA, pp 315-322 